\title{
Rapid detection of sacbrood virus (SBV) by one- step reverse transcription loop-mediated isothermal amplification assay
}

\author{
Yang Jin-Long ${ }^{1}$, Yang Rui ${ }^{1}$, Shen Ke-Fei ${ }^{1}$, Peng Xiang-Wei ${ }^{1}$, Xiong Tao ${ }^{2}$ and Liu Zuo-Hua ${ }^{1 *}$
}

\begin{abstract}
Background: Sacbrood virus (SBV) primarily infects honeybee broods, and in order to deal with the problem cost effective detection methods are required.

Findings: A one-step reverse transcription loop-mediated isothermal amplification (RT-LAMP) assay was developed for the rapid identification of SBV. The data demonstrated that, in a simple water bath, SBV RNA could be detected as early as $20 \mathrm{~min}$ at $65^{\circ} \mathrm{C}$, and a positive amplification reaction was visible to the naked eye due to a color change brought on by the addition of nucleic acid stain SYBR Green.

Conclusions: The current study presents a method for the rapid and simple detection of SBV by RT-LAMP with high sensitivity and analytic specificity.
\end{abstract}

Keywords: Sacbrood virus, Loop-mediated isothermal amplification, SYBR Green, Honeybee

Sacbrood virus (SBV) primarily affects honeybee broods, and results in larval death. Infected larvae change color from pearly white to pale yellow, and shortly after death they dry out, forming a dark brown gondola-shaped scale [1]. Suitable detection methods are needed to control and eradicate SBV. Several have been developed, such as immunodiffusion assays, radioimmunoassay, enzyme-linked immunosorbent assay (ELISA), and qualitative PCR [2]. However, in contrast to these assays, reverse transcription loop-mediated isothermal amplification (RT-LAMP) does not require expensive or special equipment $[3,4]$. Therefore, LAMP-based detection assays would be suitable for on-the-spot detection in the field or primitive laboratories. The aim of this study was to develop a novel method for the detection of SBV in a simple, rapid and cost-effective manner.

A set of six specific primers was designed by targeting the sequence of the SBV-pol gene sequence (GenBank accession no. AF092924.1) using Primer Explorer version 3 (http://primerexplorer.jp/e/intro/index.html). The nucleotide sequences of the primers are shown in Table 1.

\footnotetext{
*Correspondence: a512156093@qq.com

${ }^{1}$ Chongqing Academy of Animal Science, Chongqing 402460, China

Full list of author information is available at the end of the article
}

A brood of honeybees known to be infected with Sacbrood virus (SBV) were kindly provided by Dr. S. KF from Chongqing Academy of Animal Science. All samples were stored at $-20^{\circ} \mathrm{C}$ before RNA extraction. Total RNA was extracted from SBV isolates using an RNA extraction kit (TaKaRa Biotechnology, Dalian, China) according to the manufacturer's protocol. Total RNA was resuspended in water and quantified by spectrophotometry [5]. The RTLAMP reaction was carried out in a $25 \mu \mathrm{l}$ reaction mixture containing $2 \mu \mathrm{M}$ each of the inner primers FIP and BIP, $0.2 \mu \mathrm{M}$ each of the outer primers F3 and B3, $1.4 \mathrm{mM}$ deoxyribonucleotide triphosphate (dNTP) mix (TaKaRa Biotechnology, Dalian, China.), $5 \mathrm{mM} \mathrm{MgSO}$, 16 units of Bacillus stearothermophilus (Bst) DNA polymerase (New England Biolabs Inc., Ipswich, MA), $1 \times$ the supplied Bst DNA polymerase buffer, 0.125 units of AMV reverse transcriptase, and $2 \mu \mathrm{l}$ of template RNA. The RT-LAMP reaction mixtures were incubated at the optimal reaction temperature $\left(65^{\circ} \mathrm{C}\right)$ for the optimal reaction time $(50 \mathrm{~min})$ and were finally heat inactivated at $85^{\circ} \mathrm{C}$ for $2 \mathrm{~min}$ to terminate the reaction.

The RT-LAMP assay successfully amplified the target sequence of the SBV-pol gene, as observed by $2 \%$ agarose gel electrophoresis. The effect could also be seen by
C Biomed Central

() 2012 Jin-Long et al; licensee BioMed Central Ltd. This is an Open Access article distributed under the terms of the Creative Commons Attribution License (http://creativecommons.org/licenses/by/2.0), which permits unrestricted use, distribution, and reproduction in any medium, provided the original work is properly cited. 
Table 1 The reverse transcription loop-mediated isothermal amplification (RT-LAMP) primer sets

\begin{tabular}{|c|c|c|c|c|c|}
\hline Primer & Type & 5'pos & 3'pos & Length & Sequence $\left(5^{\prime}\right.$ to $\left.-3^{\prime}\right)$ \\
\hline F3 & Forward outer & 519 & 539 & $21-n t$ & AAGGAACTATAGTATGGCGAA \\
\hline B3 & Backward outer & 707 & 724 & $18-n t$ & CTGTTGCTGGTCTCTTGT \\
\hline \multirow[t]{2}{*}{$\overline{F I P}$} & Forward inner & 592 & 616 & 46-mer(F1c:25-nt, & TGGACCTACAAATTGCACCAATATA- \\
\hline & $(F 1 c+F 2)$ & 548 & 568 & F2:21-nt) & ACCTCTTACAGTTGCAAAGTG \\
\hline \multirow[t]{2}{*}{$\mathrm{BIP}$} & Backward & 619 & 640 & 44-mer (B1c:22-nt, & AAGGACCCAGAGTGATGAGGTA- \\
\hline & inner(B1C + B2) & 679 & 700 & B2:22-nt) & TGTATITTCTTCCTTGGAACTT \\
\hline$\overline{L F}$ & Loop Forward & 569 & 591 & $23-n t$ & CTCTTAGCTGCTAGTTCTGAAGC \\
\hline $\mathrm{LB}$ & Loop Backward & 641 & 663 & $23-n t$ & CCCTCGAAAGAATCTATTCAGGG \\
\hline
\end{tabular}

the naked eye on addition of $1.0 \mu \mathrm{l} 1,000$-fold diluted original SYBR Green I (Molecular Probes, Inc.). The solution changed from light orange to green in the presence of LAMP amplicons, while it remained light orange in the absence of amplification. Amplified DNA in the LAMP reaction causes white turbidity due to the accumulation of magnesium pyrophosphate, a by-product of the reaction. Prior to the addition of SYBR Green I, the white turbidity of the reaction mixture by magnesium pyrophosphate was also inspected [3].

Temperature and reaction duration are critical parameters in RT-LAMP reaction. To determine the optimal reaction temperature, the RT-LAMP reactions were carried out for $60 \mathrm{~min}$ at $59^{\circ} \mathrm{C}, 60^{\circ} \mathrm{C}, 61^{\circ} \mathrm{C}, 62^{\circ} \mathrm{C}, 63^{\circ} \mathrm{C}, 64^{\circ}$ $\mathrm{C}$ and $65^{\circ} \mathrm{C}$. The DNA products from all reactions except that done at $59^{\circ} \mathrm{C}$ showed an obvious ladder-like pattern on the gel. The intensities of the DNA products at $63^{\circ} \mathrm{C}, 64^{\circ} \mathrm{C}$ and $65^{\circ} \mathrm{C}$ were higher than those at other temperatures (Figure 1). Therefore, $63^{\circ} \mathrm{C}-65^{\circ} \mathrm{C}$ was considered the optimal temperature range for RT-LAMP reaction for the detection of SBV.

To determine the optimal reaction time, the total reaction mixture was incubated at $65^{\circ} \mathrm{C}$ for $10,20,30$,

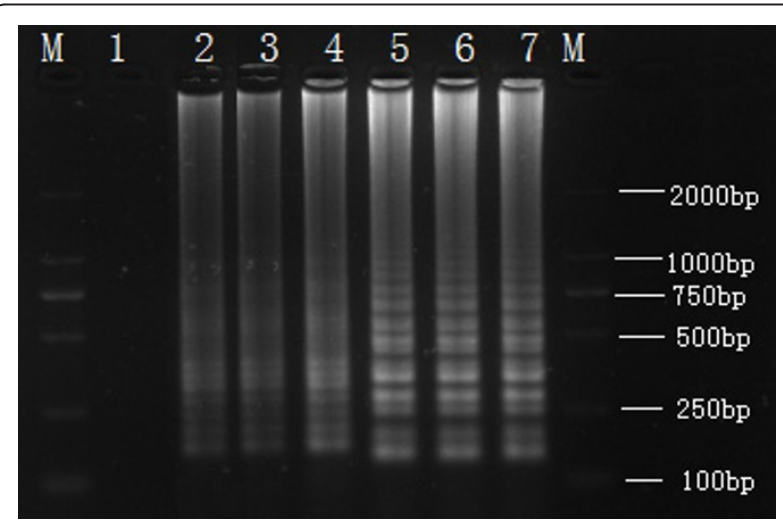

Figure 1 Determination of the optimal temperature of the LAMP. Determination of the optimal temperature. Lane $\mathbf{M}, \mathrm{DL}-2000$ DNA marker; Lanes 1-7: LAMP carried out at 59, 60, 61, 62, 63, 64 and $65^{\circ} \mathrm{C}$.
40 , and $50 \mathrm{~min}$. The DNA products from the reaction with a duration of between 30 and 50 min showed the highest intensity and the earliest detection time was 20 min (Figure 2). Therefore, 30-50 min was considered the optimal reaction time range for the RT-LAMP reaction. The final, optimal RT-LAMP protocol was therefore determined to be for a time of between 30 and 50 min at a temperature in the range $63^{\circ} \mathrm{C}-65^{\circ} \mathrm{C}$.

The RT-LAMP product was detected using the naked eye by observing the white turbidity of the reaction mixture (Figure 3A) or color change of the solution when stained with SYBR Green I (Figure 3B).

Figure $3 \mathrm{~A}$ shows that white turbidity was observed in reaction products when using samples with between 1.0 $\times 10^{2}$ copies/ $\mu$ l to $1.0 \times 10^{4}$ copies $/ \mu$ l of standard template RNA. However, this was not observed in samples with between $1.0 \times 10^{0}$ to $1.0 \times 10^{1}$ copies $/ \mu$ l.

In Figure 3B, after adding $1 \mu \mathrm{l}$ of diluted SYBR Green I to the reaction tube, the color of the RT-LAMP reaction solution changed from orange to green in samples

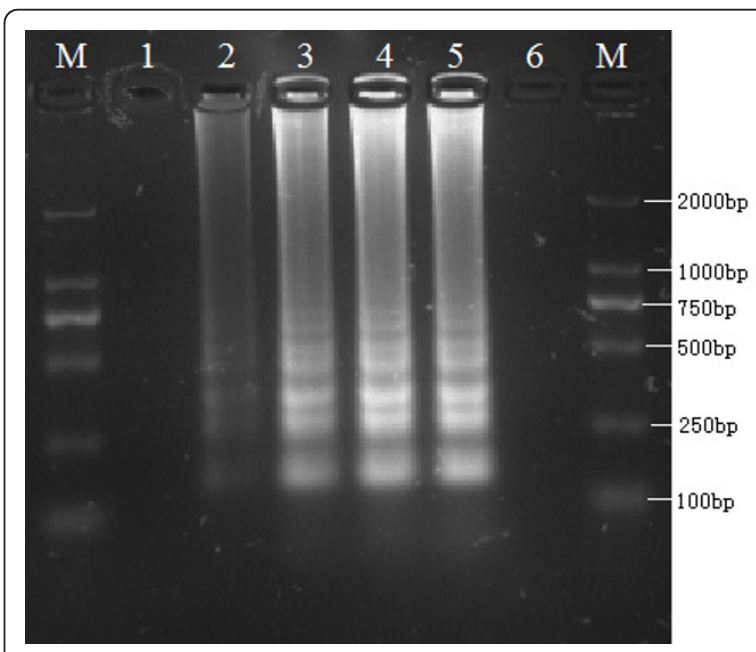

Figure 2 Determination of the optimal time of the LAMP. Lane M, DL-2000 DNA marker; Lanes 1-5: LAMP carried out for 10, 20, 30, 40 and 50 min, respectively; Lane 6: -, negative control. All products were electrophoresed on $2 \%$ agarose gels and stained with ethidium bromide. 

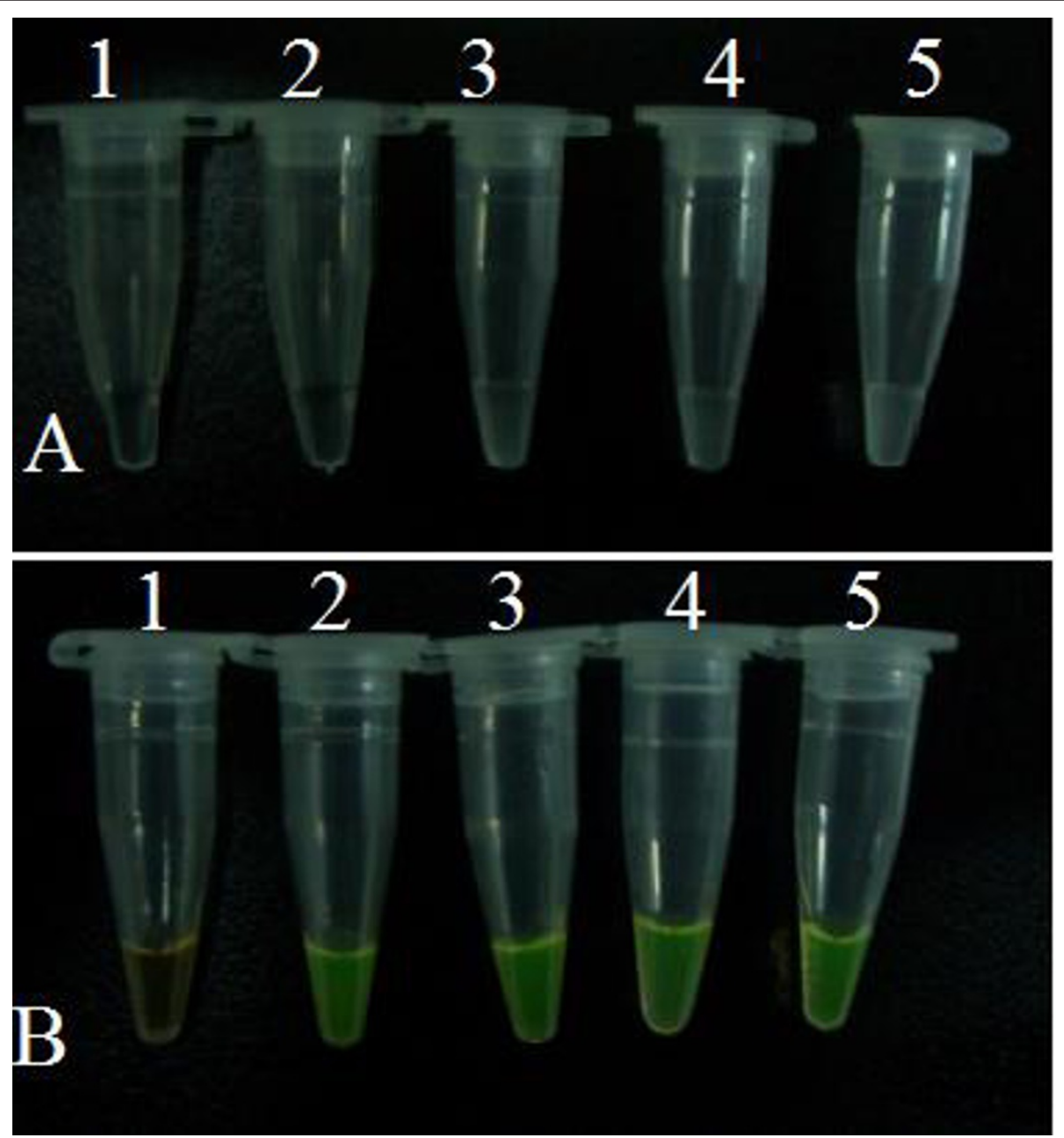

Figure 3 Detection of LAMP products by observing white turbidity and color of the reaction mixture. (A) Shows white turbidity of the reaction mixture by magnesium pyrophosphate; (B) Shows color (green) of the reaction mixture after adding SYBR Green I. 1-5, reaction carried out using 10-fold serial dilutions of standard SBV DNA $\left(1.0 \times 10^{4}\right.$ copies/ $\left.\mu \mathrm{L}\right): 1: 1.0 \times 10^{0}, 2: 1.0 \times 10^{1}, 3: 1.0 \times 10^{2}, 4: 1.0 \times 10^{3}$, and 5: 1.0 $\times 10^{4}$ copies/ $\mu \mathrm{L}$, respectively.

with between $1.0 \times 10^{1}$ copies $/ \mu \mathrm{l}$ to $1.0 \times 10^{4}$ copies $/ \mu \mathrm{l}$ of standard template RNA. No color change was observed in $1.0 \times 10^{\circ}$ copies $/ \mu$ l.

Taken together, these results show that the RT-LAMP detection limit is $1.0 \times 10^{2}$ copies for white turbidity assay, and $1.0 \times 10^{1}$ copies for analysis with SYBR Green I. Therefore, we conclude that color observation method (using SYBR Green I) was ten times more sensitive than the white turbidity observation.

The specificity of the RT-LAMP assay was determined with SBV isolates and other honeybee viruses (deformed wing virus (DWV), chronic bee paralysis virus (CBPV), Kashmir bee virus (KBV)). All SBV strains were positive while all other honeybee viruses were negative. This demonstrates that the RT-LAMP assay is specific, with no cross-reaction with other honeybee viruses.
To evaluate the application of RT-LAMP to detect SBV in clinical samples, the test was performed on 30 field clinical samples collected in Chongqing, China, in the period March to May 2011. These were obtained from broods in apiaries with unusually high mortality, which was suspected to be due to SBV infection. The tests yielded 27 positive and three negative results by both RT-LAMP and RT-PCR assays [6].

In summary, the current study presents a method for the rapid detection of SBV by RT-LAMP with high sensitivity and analytic specificity. The assay is feasible for use in less well-equipped laboratories as well as in the field.

\section{Acknowledgements}

This work was supported by the earmarked fund for Modern Agro-industry Technology Research System(No. CARS-43-15) and the special fund of Chongqing key laboratory (CSTC). 


\section{Author details}

'Chongqing Academy of Animal Science, Chongqing 402460, China.

${ }^{2}$ Rongchang Bureau of Animal Husbandry, Chongqing 402460, China.

\section{Authors' contributions}

$J Y, Y R$ and KS carried out most of the experiments and wrote the manuscript, and should be considered as first authors. XP and ZL critically revised the manuscript and the experiment design. TX helped with the experiment. All of the authors read and approved the final version of the manuscript.

\section{Competing interests}

The authors declare that they have no competing interests.

Received: 10 June 2011 Accepted: 17 February 2012

Published: 17 February 2012

\section{References}

1. Ritter W: Diagnostik und Bekämpfung von Bienenkrankheiten Stuttgart: Gustav Fischer Verlag Jena; 1996, 104-114.

2. Grabensteiner E, Ritter W, Carter MJ, Davison S, Pechhacker H, Kolodziejek J, Boecking O, Derakhshifar I, Moosbeckhofer R, Licek E, Nowotny N: Sacbrood Virus of the Honeybee (Apis mellifera): rapid identification and phylogenetic analysis using reverse transcription-PCR. Clin Vaccine Immunol 2001, 1:93-104.

3. Notomi T, Okayama H, Masubuchi H, Yonekawa T, Watanabe K, Amino N, Hase T: Loop-mediated isothermal amplification of DNA. Nucleic Acids Res 2000, 28:63.

4. JinLong Yang, Rui Yang, AnChun Cheng, MingShu Wang, LiZhi Fu, SongQuan Yang, SuHui Zhang, Liu Yang, ZhiYong Xu: A simple and rapid method for detection of Goose Parvovirus in the field by loop-mediated isothermal amplification. Virol J 2010, 7:14.

5. Ke GM, Cheng HL, Ke LY, Ji WT, Chulu JL, Liao MH, Chang TJ, Liu HJ: Development of a quantitative Light Cycler real-time RT-PCR for detection of avian reovirus. J Virol Meth 2006, 1:6-13.

6. Liang ZHOU, Zhan-yun SONG, Quan-kai WANG, Jin-hua LIU, Li-gang XUE, Zhen-guo WANG: RT-PCR detection for the honey bee sacbrood virus disease (in Chinese). J Bee 2010, 6:9-10.

doi:10.1186/1743-422X-9-47

Cite this article as: Jin-Long et al:: Rapid detection of sacbrood virus (SBV) by one-step reverse transcription loop-mediated isothermal amplification assay. Virology Journal 2012 9:47.

\section{Submit your next manuscript to BioMed Central and take full advantage of:}

- Convenient online submission

- Thorough peer review

- No space constraints or color figure charges

- Immediate publication on acceptance

- Inclusion in PubMed, CAS, Scopus and Google Scholar

- Research which is freely available for redistribution

Submit your manuscript at www.biomedcentral.com/submit
C Biomed Central 